WARSZTATY Z GEOGRAFII TURYZMU

ISBN 978-83-7969-262-0 $\quad$ s. 239-253

http://dx.doi.org/10.18778/7969-262-0.16

Anna PRZYBYLSKA

Uniwersytet im. Adama Mickiewicza w Poznaniu

\title{
INNOWACYJNOŚĆ PRZEDSIĘBIORSTW TURYSTYCZNYCH NA RYNKU WIELKOPOLSKIM
}

\section{Wprowadzenie}

Warunkiem przetrwania przedsiębiorstwa jest jego rozwój. W celu zapewnienia trwałej przewagi konkurencyjnej konieczne jest poszukiwanie rozwiązań organizacyjnych, technicznych, technologicznych oraz produktowych stwarzających jednocześnie możliwość konkurowania i osiągania sukcesów rynkowych. Siłą konkurencji przedsiębiorstw turystycznych na rynku są często wprowadzane innowacje, które dzięki zastosowaniu nowych kombinacji aktualnie dostępnych czynników produkcji obsługują nowe rynki lub nabywają środki produkcji na nowych rynkach (SCHUMPETER 1960). Innowacje są bezpośrednio związane ze zmianami w przedsiębiorstwie, instytucji czy organizacji. Nie każda zmiana jest uznawana za innowację. Staje się nią wtedy, gdy zostaje zaakceptowana przez interesariuszy i utrwalona poprzez standardowe praktyki, procedury i procesy produkcyjne wpływające na końcowy produkt, gospodarkę przedsiębiorstwa i kraju (FABIŃSKA, CZYŻ, KUBIAK, GUNERSKA 2010). Innowacyjność gospodarki każdego regionu wynika z licznych uwarunkowań, do których należy zaliczyć: 
- czynniki wewnętrzne (tzw. zasobowe - wynikają z wykorzystania zasobów pracy i warunków techniczno-ekonomicznych przedsiębiorstwa $\left.{ }^{1}\right)$;

- czynniki zewnętrzne (wynikające z bezpośrednich impulsów lub barier bliższego i dalszego otoczenia prawnego, rynkowego, politycznego, instytucjonalnego oraz przestrzennego, w którym funkcjonuje przedsiębiorstwo);

- czynniki otoczenia dalszego (identyczne dla wszystkich regionów w kraju, jedyne różnice międzyregionalne, jakie mogą się pojawić, wynikają z umiejętności wykorzystania szans $\mathrm{z}$ otoczenia oraz unikania zagrożenia, jak również z umiejętności adaptacji do zmian bądź ich antycypowania ${ }^{2}$ )

- czynniki otoczenia bliższego (wynikające bezpośrednio z sytuacji lokalnej i regionalnej, na którą składa się również działalność władz samorządowych ${ }^{3}$ ) (GACZEK 2009).

Województwo wielkopolskie jest uznawane za region dosyć dobrze rozwinięty (EUROSTAT; za: GACZEK 2009). Wynika to przede wszystkim z wartości regionalnego produktu per capita, który osiąga najwyższą wartość zaraz po województwie mazowieckim i śląskim. Jednak wartość dodana brutto na jednego pracującego jest niższa od średniej krajowej. Wynik takiej sytuacji jest uzasadniany wyższym $\mathrm{w}$ regionie niż $\mathrm{w}$ kraju udziałem rolnictwa przy niższym udziale usług w wytwarzaniu wartości dodanej (GUS za: GACZEK 2009). Dodatkowo region ten charakteryzuje się znacznym zróżnicowaniem

1 Składają się na nie przede wszystkim kapitał ludzki i kapitał intelektualny firmy oraz zasoby (aktywa) kapitałowe przedsiębiorstwa, które wskazują na zaawansowanie technologiczne w łańcuch kooperacji branżowej i międzygałęziowej, nowoczesność parku maszynowego i wykorzystywane technologie oraz bardzo istotne $\mathrm{w}$ przedsiębiorstwach usługowych - stosowane systemy zarządzania.

2 Na przykład: warunki makroekonomiczne, regulacja zakresu swobody gospodarczej, krajowy system innowacyjny, cechy systemu bankowego, polityka badawczo-rozwojowa kraju, dostępność do technologii, zdolność budżetu państwa do finansowania badań naukowych, specyfika krajowego rynku itd.

${ }^{3}$ Uwarunkowania te ograniczają albo sprzyjają występowaniu i rozwojowi innowacyjności przedsiębiorstw. Do najważniejszych tego typu czynników zaliczono: naturalne i demograficzne zasoby regionu, zasoby materialne, potencjał naukowo-badawczy, kapitał ludzki i społeczny regionu, ukształtowane instytucje, wewnętrzna polityka regionu, polityka innowacyjna regionu, stan infrastruktury technicznej oraz wpływ poszczególnych interesariuszy na możliwość funkcjonowania przedsiębiorstwa.

${ }^{4}$ W 2004 r. w województwie wielkopolskim rolnictwo wytworzyło 8,9\%, przemysł 26,4\%, budownictwo 5,8\%, a usługi 59\% WDB. Dla Polski wartości te odpowiednio były następujące: 5\%, $24,9 \%, 5,3 \%$ i $64,7 \%$. 
wewnętrznym, m.in. wynikającym $\mathrm{z}$ faktu koncentracji potencjału naukowo-badawczego w centralnej części województwa, a zdecydowanie niższym potencjałem w peryferyjnych jego częściach. Przewaga województwa wielkopolskiego nie występuje w odniesieniu do wskaźników przeciętnych wynagrodzeń, poziomu wykształcenia ludności, a także mierników obrazujących działalność badawczo-rozwojową i poziom innowacyjności gospodarki (GACZEK 2009). Liczba przedsiębiorstw innowacyjnych w przemyśle i w usługach w województwie wielkopolskim była także niższa niż średnio w kraju. W ciągu kilku ostatnich lat również nakłady na działalność innowacyjną przedsiębiorstw przemysłowych i usługowych zostały obniżone. Przedsiębiorstwa aktywne innowacyjnie (ponoszące nakłady na innowacje) w sektorze usług to zaledwie 28,3\% ogólnej liczby przedsiębiorstw (dane z 2006 r.). Taka sytuacja powoduje zauważalny spadek zaangażowania innowacyjnego przedsiębiorstw (rozumiany jako udział przedsiębiorstw ponoszących nakłady na innowacje w ogólnej liczbie przedsiębiorstw przemysłowych lub usługowych). Zdecydowanie można to traktować jako sytuację niekorzystnie wpływającą na podnoszenie innowacyjności gospodarki oraz budowanie przewagi konkurencyjności regionu. Do najważniejszych elementów decydujących o tym należy zaliczyć:

- niewystarczające zaangażowanie sektora przedsiębiorstw w finansowanie badań i rozwoju;

- duże wahania w czasie przeznaczanych na działalność innowacyjną przedsiębiorstw środków finansowych;

- brak wyraźnego trendu wzrostu nakładów finansowych na działalność innowacyjną przedsiębiorstw od roku 2004;

- niewystarczającaą wartość (liczba i jakość) zasobów ludzkich dla nauki i techniki (GACZEK 2009).

Niestety należy zauważyć, że przedstawiona sytuacja dynamicznie ulega zmianie ze względu na przemiany społeczno-gospodarcze, co powoduje, że z roku na rok ważność wspomnianych czynników może być inna. Nie tylko każdy rodzaj działalności wytwórczej, ale również sfera usług jest jednym ze źródeł przewagi konkurencyjnej. Innowacyjność w tym zakresie przejawia się przede wszystkim $w$ wytwarzanych produktach, usługach, elementach zarządzania przedsiębiorstwem, logistyce, czy również w kontaktach z otoczeniem. Za najważniejszy element innowacji w działalności usługowej uważa się relację klient-usługodawca, który jest istotą działalności usługowej. Natomiast najważniejszą rolę w generowaniu innowacyjności przedsiębiorstwa odgrywają jego pracownicy zarówno niższego, jak i wyższego szczebla. 
Wynika to przede wszystkim z faktu, że w tego typu działalności brakuje jednostek organizacyjnych odpowiedzialnych za innowacje w przedsiębiorstwie. Dodatkowo należy zwrócić uwagę na fakt, że przedsiębiorstwa te nie posiadają również wyodrębnionych komórek naukowo-badawczych, nie patentują, co w istotny sposób ogranicza działalność innowacyjną. To nowości w zakresie innych działalności są zazwyczaj implikowane na rynek turystyczny.

Przeprowadzone na terenie Wielkopolski badania w małych i średnich przedsiębiorstwach, wskazują jednoznacznie, że aż 53\% firm usługowych w ostatnich kilku latach nie wprowadziło żadnej innowacji, natomiast te, którym się udało, na źródło innowacji wskazują własne doświadczenia (MAZGAJSKA 2002). Na skutek upływu lat od ostatnich prowadzonych badań na terenie województwa wielkopolskiego, a tym samym zmiany znaczenia i wpływu innowacji na możliwości rozwoju przedsiębiorstw, podjęto próbę zaktualizowania wiedzy dotyczącej rozwiązań innowacyjnych $w$ sektorze małych i średnich przedsiębiorstw.

Badania empiryczne przeprowadzone przez autorkę zostały poprzedzone licznymi studiami literaturowymi dotyczącymi innowacyjności w gospodarce rynkowej kraju. Większość dostępnych źródeł dotyczy innowacyjności gospodarki i adaptacji usług turystycznych do panujących warunków. Podobnie szeroko w literaturze został opisany problem przedsiębiorczości i jego wpływu na innowacyjność branży turystycznej. Najmniej publikacji w literaturze polskiej dotyczy zakresu typowej innowacyjności przedsiębiorstw turystycznych, jak również wskazania rekomendacji do aspektów utrudniających wprowadzanie rozwiązań innowacyjnych.

\section{Cel i metoda badań}

Przeprowadzone badania miały na celu identyfikację poziomu wiedzy przedsiębiorców na temat innowacyjności ogółem oraz możliwości zastosowania rozwiązań innowacyjnych w przedsiębiorstwach rekreacyjno-turystycznych. Dodatkowo badania wskazały konkretne rozwiązania innowacyjne, jakie są stosowane przez przedsiębiorstwa. Właściciele firm poproszeni zostali również o wskazanie czynników bezpośrednio przyczyniających się do obniżenia bądź też do promowania innowacyjnych rozwiązań w działalności turystycznej. Badania miały charakter wywiadu pogłębionego przy wykorzystaniu kwestionariusza skategoryzowanego. Kwestionariusz 
był tak skonstruowany, aby zebrać wszystkie niezbędne informacje dotyczące innowacyjnych rozwiązań w taki sposób, aby nabrały one charakteru porównywalnego z pozostałymi wynikami badań przeprowadzonych wśród przedsiębiorców.

W pierwszym półroczu roku 2013 zostało przebadanych 46 przedsiębiorstw turystycznych zlokalizowanych na terenie województwa wielkopolskiego. Na specyfikę grupy badawczej składało się: 26 obiektów noclegowych (23 hotele i trzy hostele), 12 biur podróży oraz osiem przedsiębiorstw określanych w pracy jako „inne” (dwa baseny, jedna wypożyczalnia samochodów, dwie restauracje, jeden sklep ze sprzętem rekreacyjno-turystycznym, dwie kawiarnie). Dobór próby badawczej miał charakter losowy i stanowił około $5 \%$ obiektów noclegowych i biur podróży zlokalizowanych w województwie wielkopolskim. Wybór grupy docelowej wynikał bezpośrednio z definicji zaproponowanej przez A. RAPACZA (red. 1998): która określa przedsiębiorstwo turystyczne jako „celowo zorganizowany, samodzielny ekonomicznie i wyodrębniony pod względem techniczno-usługowym, przestrzennym oraz prawnym zespół ludzi, środków materialnych i finansowych powołany do prowadzenia określonej działalności gospodarczej, zaspokajającej potrzeby ludności w sferze turystyki i pozwalającej na maksymalizację jego korzyści". Próba badawcza została zróżnicowana na podstawie kryterium funkcjonalnego, uwzględniającego rodzaj świadczonych usług 5 .

\section{Wyniki badań}

Znaczenie słowa „innowacyjność” charakteryzuje się niemałym subiektywizmem. Jest ono rozumiane przez przedsiębiorców w różny sposób. Do najczęstszych wypowiedzi z jednej strony podobnych, a jednak zdecydowanie odróżniających się należały:

- innowacyjność to nowoczesność sprzętu, dobra organizacja i coś, co odróżnia nas od innych;

- to ciągłe ulepszenie, doskonalenie usług, systemu pracy, wprowadzanie nowych pomysłów i technologii;

${ }^{5}$ Przy uwzględnieniu tego kryterium przedsiębiorstwa turystyczne można podzielić na: transportowe, hotelarsko-gastronomiczne, uzdrowiskowe, sportowo-rekreacyjne oraz biura podróży, będące łącznikiem między wytwórcami usług a turystami (organizatorzy, pośrednicy, agenci). 
- to sposób myślenia, który niczego nie zakłada z góry; przełamując stereotypy pozwala tworzyć nowe, zaskakujące i odpowiadające na potrzeby innych produkty i usługi;

- prowadzenie badań nad rozwojem produktu, poprawa jego funkcjonalności i atrakcyjności;

- jest to gotowość próbowania tego, co nieznane i ryzykowne;

- to generowanie nowych produktów i usług, które wyróżniają firmę na tle innych bądź też które mogą przynieść korzyści przedsiębiorstwu;

- poszukiwanie obszarów działania skutkujących wzrostem wydajności pracy wraz z podniesieniem jakości warunków pracy;

- to tworzenie nowych produktów i usług, które zwiększają dobrobyt społeczny;

- działalność mająca na celu zapewnienie firmie zysk z inwestycji, natomiast społeczeństwu zapewnia rozwój i dobrobyt;

- przewidywanie przyszłych potrzeb klienta i reagowanie na te potrzeby.

Takie pojmowanie innowacyjności $\mathrm{w}$ dużej mierze wpłynęło na wyniki przeprowadzonych badań kwestionariuszowych. Przedsiębiorstwa, które wiązały określenie innowacyjności z podjęciem jakichkolwiek działań, które przynoszą zysk firmie, w rzeczywistości nie wprowadzały zasadniczych zmian, tym bardziej o charakterze innowacyjnym. Poziom innowacyjności podmiotów gospodarczych powinien być zawsze wynikiem przyjmowanych przez przedsiębiorstwo celów, podejmowanych obszarów działalności oraz dostępności wsparcia na działalność innowacyjną. Niestety, badanie poziomu świadomości przedsiębiorców w aspekcie znaczenia słowa „innowacyjność" i możliwości odniesienia tego typu rozwiązań na rynek turystyczny wskazało jednoznacznie, że nie potrafiąc zdefiniować tego określenia, również nie są w stanie przenieść tego typu rozwiązań na funkcjonowanie przedsiębiorstwa turystycznego.

Przedsiębiorstwo aktywne innowacyjnie to takie, które w określonym aspekcie czasowym wprowadziło przynajmniej jedną innowację: produktową/ usługową, procesową, marketingową albo organizacyjną (Działalność innozvacyjna... 2012, s. 21, zmodyfikowana). Przeprowadzone badania wskazały, że innowacyjność na rynku turystycznym rozwija się prężnie. Tylko dwa z 46 przedsiębiorstw zadeklarowało $(4,4 \%)$, że nie uważa się za innowacyjne. W obu przypadkach decyzję swoją uzasadniały chęcią nie wyróżniania się na tle innych. Przeprowadzone badania wykazały, że z pozostałych 44 przed- 
siębiorstw, które zadeklarowały się jako średnio innowacyjne, w dwóch przedsiębiorstwach $\mathrm{w}$ ciągu ostatnich trzech lat nie zostały wprowadzone żadne innowacyjne rozwiązania (rys. 1).

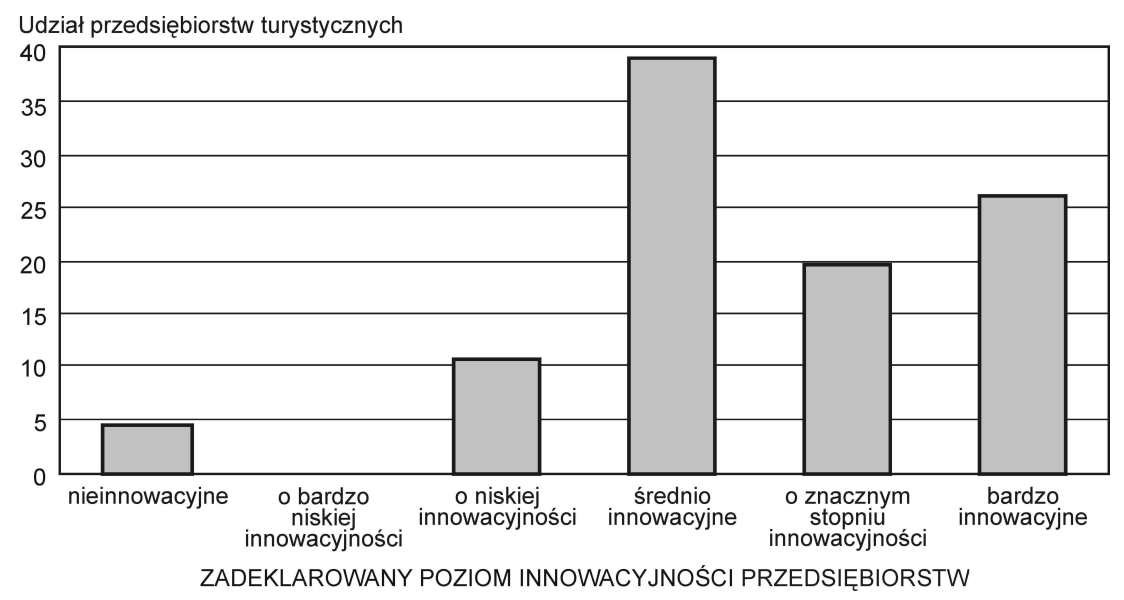

Rys. 1. Poziom innowacyjności przedsiębiorstw turystycznych w województwie wielkopolskim

Źródło: opracowanie własne na podstawie przeprowadzonych badań

Przeprowadzone badania wskazują, że właściciele przedsiębiorstw turystycznych w województwie wielkopolskim uważają, że ich firmy są innowacyjne na skalę krajową. Żaden z przedsiębiorców nie deklaruje, iż podejmowane działania $\mathrm{w}$ zakresie rozwiązań innowacyjnych są unikatowe na skalę europejską. Zasięg krajowy rozwiązań innowacyjnych wynika przede wszystkim z faktu zróżnicowania grupy badawczej, a co za tym idzie, na rynku polskim nadal obserwuje się niewiele przedsiębiorstw o podobnym profilu działania (np. Juice Drinkers). Dodatkowo nadal rozwiązania w zakresie nowoczesnego "designu” nie są standardem nawet na skalę kraju (np. hotel Andersia).

Najważniejsza część przeprowadzonych badań polegała na identyfikacji innowacyjnych rozwiązań wprowadzonych przez wielkopolskie przedsiębiorstwa. Ze względu na unikatowy charakter stosowanych innowacji nie było możliwości dokonania standaryzacji i porównywalności rozwiązań. Innowacyjność na rynku usług turystycznych w województwie wielkopolskim przejawiała się tym, że większość rozwiązań zakwalifikowano jako nowe bądź ulepszane produkty czy usługi. Zdecydowanie silną grupę wymienia- 
nych produktów stanowiły rozwiązania sprzyjające ochronie środowiska zarówno w aspekcie prowadzania nowych usług, jak również w zakresie rozwiązań organizacyjnych $w$ przedsiębiorstwie. Zebrane rozwiązania uszeregowano $\mathrm{w}$ tab. 1 zgodnie $\mathrm{z}$ przyjętym przez autora pracy podziałem na: innowacje produktowe/ usługowe $^{6}$, procesowe $^{7}$, marketingowe ${ }^{8}$ oraz organizacyjne ${ }^{9}$.

${ }^{6}$ Wprowadzenie na rynek wyrobu lub usługi, które są nowe lub istotnie ulepszone w zakresie swoich cech lub zastosowań. Zalicza się tu znaczące udoskonalenia pod względem specyfikacji technicznych, komponentów i materiałów, wbudowanego oprogramowania, łatwości obsługi lub innych cech funkcjonalnych.

Innowacja produktowa może być wynikiem zastosowania nowej wiedzy lub technologii bądź nowych zastosowań lub kombinacji istniejącej wiedzy i technologii. Innowacje produktowe w zakresie usług polegają na wprowadzeniu znaczących udoskonaleń w sposobie świadczenia usług, na dodaniu nowych funkcji lub cech do istniejących usług lub na wprowadzeniu całkowicie nowych usług (www.stat.gov.pl; 28.10.2013).

7 Wdrożenie nowych lub istotnie ulepszonych metod produkcji, dystrybucji i wspierania działalności w zakresie wyrobów i usług. Metody produkcji to techniki, urządzenia i oprogramowanie wykorzystywane do produkcji (wytwarzania) wyrobów lub usług. Metody dostawy dotyczą logistyki przedsiębiorstwa i obejmują urządzenia, oprogramowanie i techniki wykorzystywane do nabywania środków produkcji, alokowania zasobów w ramach przedsiębiorstwa lub dostarczania produktów końcowych. Do innowacji procesowych zalicza się nowe lub znacząco ulepszone metody tworzenia i świadczenia usług. Mogą one polegać na znaczących zmianach w zakresie sprzętu i oprogramowania wykorzystywanego dla działalności usługowej lub na zmianach $\mathrm{w}$ zakresie procedur i technik wykorzystywanych do świadczenia usług. Innowacje procesowe obejmują także nowe lub istotnie ulepszone techniki, urządzenia i oprogramowanie $\mathrm{w}$ działalności pomocniczej takiej jak zaopatrzenie, księgowość, obsługa informatyczna i prace konserwacyjne(www.stat.gov.pl; 28.10.2013).

8 Wdrożenie nowej koncepcji lub strategii marketingowej różniącej się znacząco od metod marketingowych dotychczas stosowanych $\mathrm{w}$ przedsiębiorstwie. Obejmuje znaczące zmiany $\mathrm{w}$ projekcie/konstrukcji produktów, opakowaniu, dystrybucji produktów, promocji produktów i kształtowaniu cen. Nie zalicza się tu zmian sezonowych, regularnych i innych rutynowych zmian w zakresie metod marketingowych.

Nowe metody marketingowe w zakresie dystrybucji produktów polegają przede wszystkim na wprowadzeniu nowych kanałów sprzedaży. Nowe metody marketingowe w zakresie promocji produktów polegają na stosowaniu nowych koncepcji promowania wyrobów i usług przedsiębiorstwa. Innowacje w zakresie kształtowania cen polegają na zastosowaniu nowych strategii cenowych dla sprzedaży wyrobów lub usług przedsiębiorstwa na rynku (www.stat.gov.pl; 28.10.2013)

${ }_{9}$ Wdrożenie nowej metody organizacyjnej w przyjętych przez przedsiębiorstwo zasadach działania (w tym w zakresie zarządzania wiedzą - knowledge management), w organizacji miejsca pracy lub w stosunkach $\mathrm{z}$ otoczeniem, która nie była dotychczas stosowana w przedsiębiorstwie. Innowacje organizacyjne $\mathrm{w}$ zakresie przyjętych przez przedsiębiorstwo zasadach działania polegają na wdrażaniu nowych metod organizowania rutynowych działań i procedur regulujących pracę przedsiębiorstwa. Innowacje w zakresie organizacji miejsca pracy polegają na wdrożeniu nowych metod podziału zadań i uprawnień decyzyjnych wśród pracowników. Nowe metody organizacyjne w zakresie stosunków z otoczeniem polegają na wdrażaniu nowych sposobów organizacji stosunków $\mathrm{z}$ innymi przedsiębiorstwami lub instytucjami publicznymi (www.stat.gov.pl; 28.10.2013). 
Tabela 1. Innowacyjne rozwiązania wprowadzone w ciągu ostatnich trzech lat w wielkopolskich przedsiębiorstwach turystycznych

\begin{tabular}{|c|c|}
\hline Innowacje produktowe & Innowacje organizacyjne \\
\hline [1] & [2] \\
\hline $\begin{array}{l}\text { - regionalne produkty, zdrowe owoce, soki } \\
\text { bez cukru, kanapki z chleba pełnoziarnis- } \\
\text { tego specjalnie wypiekanego dla Juice } \\
\text { Drinkers (regionalni sadownicy) } \\
\end{array}$ & $\begin{array}{l}\text { - } \text { zbieranie pomysłów pracowników przed- } \\
\text { siębiorstwa dotyczących innowacyjnych roz- } \\
\text { wiązań w biurze (poprzez Centrum Innowacji) }\end{array}$ \\
\hline $\begin{array}{l}\text { zastosowanie iPhone'a jako urządzenia } \\
\text { wskazującego drogę do pokoju oraz jako } \\
\text { klucz do drzwi }\end{array}$ & $\begin{array}{l}\text { innowacyjność zwiázana z ochroną środo- } \\
\text { wiska (segregacja śmieci, dbałość o ilość zuży- } \\
\text { tego papieru, wprowadzenie biletów elektro- } \\
\text { nicznych) }\end{array}$ \\
\hline $\begin{array}{l}\text { serwowanie autorskich dań szefa kuchni } \\
\text { specjalnie przygotowane na potrzeby } \\
\text { restauracji (np. zupa krem z pasternaka) }\end{array}$ & $\begin{array}{l}\text { - elektroniczne umowy z możliwością złożenia } \\
\text { podpisu elektronicznego }\end{array}$ \\
\hline $\begin{array}{l}\text { - wyposażenie restauracji - stoliki wykonane } \\
\text { z palet, siedziska z poduszek }\end{array}$ & $\begin{array}{c}\text { system obiegu dokumentów wewnątrz } \\
\text { przedsiębiorstwa (np. Hotel Rzymski) }\end{array}$ \\
\hline $\begin{array}{l}\text { - elastyczne menu - otwarcie na pomysły ze } \\
\text { strony klientów }\end{array}$ & $\begin{array}{l}\text { - używanie ekologicznych czyszczących } \\
\text { środków chemicznych }\end{array}$ \\
\hline $\begin{array}{l}\text { - } \text { dostosowanie pokoi do indywidualnych } \\
\text { potrzeb klienta (np. związanych ze wzro- } \\
\text { stem i wagą łóżka typu Kingsieze w hotelu } \\
\text { Andersia i Don Prestige) }\end{array}$ & $\begin{array}{l}\text { - } \begin{array}{l}\text { elektroniczna korespondencja zamiast } \\
\text { tradycyjnej (częściowa) }\end{array} \\
\end{array}$ \\
\hline - nowoczesne wzornictwo (np. Don Prestige) & $\begin{array}{l}\text { - } \begin{array}{l}\text { drukowanie folderów, ulotek promujących } \\
\text { hotel oraz menu na papierze z odzysku }\end{array} \\
\end{array}$ \\
\hline $\begin{array}{l}\text { - dostosowanie hotelu do potrzeb osób ze } \\
\text { zwierzętami (np. Don Prestige) }\end{array}$ & $\begin{array}{l}\text { - praca na materiałach wtórnych (np. druko- } \\
\text { wanie na papierze makulaturowym) }\end{array}$ \\
\hline - specjalizacja kuchni w daniach rybnych & - internetowa recepcja \\
\hline $\begin{array}{l}\text { - wyposażenie pokoi hotelowych w pościel } \\
\text { hipoalergiczną }\end{array}$ & - elektroniczny grafik pracy personelu \\
\hline - nowoczesny design & $\begin{array}{l}\text { - } \begin{array}{l}\text { outsourcing badań i konserwacji i napraw } \\
\text { sprzętu }\end{array} \\
\end{array}$ \\
\hline $\begin{array}{l}\text { dostosowanie oferty restauracji do potrzeb } \\
\text { klientów (np. dania wegańskie, dania dla } \\
\text { alergików, dania dla diabetyków, dania bez- } \\
\text { glutenowe, dania koszerne, dania niskobiał- } \\
\text { kowe) }\end{array}$ & $\begin{array}{l}\text { - synchronizacja meldunkowa w czasie rzeczy- } \\
\text { wistym z portalami rezerwacyjnymi }\end{array}$ \\
\hline $\begin{array}{l}\text { - nowoczesne techniki treningowe (klub } \\
\text { fitness) }\end{array}$ & - nowoczesne szkolenia dla pracowników \\
\hline $\begin{array}{l}\text { - możliwość skorzystania z Internetu podczas } \\
\text { treningu w klubie fitness (stanowiska kom- } \\
\text { puterowe z dostępem do Internetu na tere- } \\
\text { nie klubu) }\end{array}$ & $\begin{array}{l}\text { - decentralizacja odpowiedzialności pracy dla } \\
\text { pracowników firmy }\end{array}$ \\
\hline $\begin{array}{l}\text { - samowystarczalność / niezależność / odpo- } \\
\text { wiedzialność }\end{array}$ & $\begin{array}{l}\text { - } \begin{array}{l}\text { rozbudowany system nagradzania } \\
\text { pracowników przedsiębiorstwa }\end{array} \\
\end{array}$ \\
\hline
\end{tabular}




\begin{tabular}{|c|c|}
\hline [1] & [2] \\
\hline $\begin{array}{l}\text { - biuro podróży dostosowane do obsługi } \\
\text { osób niepełnosprawnych (podjazd, wyso- } \\
\text { kość biurek, szerokość drzwi) }\end{array}$ & $\begin{array}{l}\text { - rozmowy zarządu przedsiębiorstwa } \\
\text { hotelowego z gośćmi na temat wprowadzania } \\
\text { ewentualnych zmian w obiekcie }\end{array}$ \\
\hline $\begin{array}{ll}- & \text { nowe produkty (np. obozy biegowe } \mathrm{w} \\
& \text { Etiopii, maraton w Izraelu) }\end{array}$ & $\begin{array}{l}\text { - nowoczesne formy zarządzania i marketingu } \\
\text { (np. channel management) }\end{array}$ \\
\hline $\begin{array}{l}\text { organizacja wyjazdów turystycznych do } \\
\text { mniej uczęszczanych destynacji turystycz- } \\
\text { nych (np. Islandia, Skandynawia, Wietnam, } \\
\text { Laos, Kambodża, Australia, Antarktyda, } \\
\text { Iran, Irak, Tybet, Nepal, Oman, Katar) }\end{array}$ & Innowacje procesowe \\
\hline $\begin{array}{l}\text { niekonwencjonalne możliwości zakwatero- } \\
\text { wania podczas wyjazdu turystycznego (np. } \\
\text { szałas) }\end{array}$ & $\begin{array}{l}\text { - własna aplikacja dla urządzeń mobilnych } \\
\text { (Blue Sky) }\end{array}$ \\
\hline $\begin{array}{l}\text { - wykorzystanie różnych środków transportu } \\
\text { podczas organizacji imprez turystycznych } \\
\text { (np. auta terenowe, helikoptery, zwierzęta } \\
\text { typu muły, konie, wielbłądy) }\end{array}$ & $\begin{array}{l}\text { nowości technologiczne (np. Smart TV, panel } \\
\text { dotykowy umożliwiający sterowanie klimaty- } \\
\text { zacją i oświetleniem) }\end{array}$ \\
\hline $\begin{array}{l}\text { oferta wyjazdów turystycznych uwzględnia } \\
\text { udogodnienia dla osób o specjalnych } \\
\text { potrzebach, np. dla kobiet w ciąży }\end{array}$ & $\begin{array}{l}\text { - doskonała jakość materiałów (np. Don } \\
\text { Prestige) }\end{array}$ \\
\hline $\begin{array}{l}\text { - wprowadzenie nowego produktu w hotelu, } \\
\text { np. w postaci sali kinowej dostępnej dla } \\
\text { gości hotelowych }\end{array}$ & $\begin{array}{l}\text { - własny system CMS w biurze podróży (wpro- } \\
\text { wadzony w roku 2011) }\end{array}$ \\
\hline $\begin{array}{l}\text { innowacyjny design obiektu hotelowego, sty- } \\
\text { lizowany na obiekty z filmów z lat np. } 50 .\end{array}$ & - ogrzewanie podłogowe \\
\hline $\begin{array}{l}\text { wprowadzenie do katalogu ofert turystycz- } \\
\text { nych wyjazdów związanych z darktourism, } \\
\text { tanatoturystyką czy seksturystyką }\end{array}$ & $\begin{array}{l}\text { stacje dokujące dla iPhone'a, iPada, iPoda } \\
\text { w pokojach hotelowych }\end{array}$ \\
\hline $\begin{array}{l}\text { - zajęcia aqua rumba prowadzone przez } \\
\text { licencjonowanego instruktora }\end{array}$ & $\begin{array}{l}\text { - regulatory przepływu wody w urządzeniach } \\
\text { sanitarnych }\end{array}$ \\
\hline $\begin{array}{l}\text { - organizacja wyjazdów motywacyjnych dla } \\
\text { pracowników przedsiębiorstwa }\end{array}$ & - kolektory słoneczne na dachu budynku hotelu \\
\hline $\begin{array}{l}\text { - tematyczny wystrój karczmy np. w stylu } \\
\text { myśliwskim }\end{array}$ & $\begin{array}{l}\text { - instalacja mieszaczy wody z powietrzem w } \\
\text { bateriach prysznicowych }\end{array}$ \\
\hline Innowacje marketingowe & $\begin{array}{l}\text { - stosowanie urządzeń elektrycznych z } \\
\text { certyfikatem Energy Star }\end{array}$ \\
\hline - reklama - wlepki (naklejki) & $\begin{array}{l}\text { - nowoczesne produkty, np. multimedialna } \\
\text { zjeżdżalnia "Czarna Dziura" z efektami } \\
\text { świetlanymi i dźwiękowymi }\end{array}$ \\
\hline $\begin{array}{l}\text { - liczne kampanie w mediach społecznoś- } \\
\text { ciowych (facebook, twister, youtube, g+, } \\
\text { pinterest) }\end{array}$ & $\begin{array}{l}\text { wykorzystanie transponderów - specjalnej } \\
\text { opaski na rękę, która jest wyposażana w ele- } \\
\text { ktroniczny chip, pełniący funkcję klucza do } \\
\text { szafki w szatni, karty płatniczej oraz prze- } \\
\text { pustki pomiędzy poszczególnymi strefami } \\
\text { obiektu }\end{array}$ \\
\hline
\end{tabular}




\begin{tabular}{|l|l|}
\hline \multicolumn{1}{|c|}{$[1]$} & \multicolumn{1}{|c|}{$[2]$} \\
\hline \begin{tabular}{l} 
- $\begin{array}{l}\text { badania rynku (ankiety powyjazdowe bada- } \\
\text { jące satysfakcje klientów, ocena preferencji } \\
\text { klientów) }\end{array}$ \\
\hline- promocja marki na gadżetach
\end{tabular} & $\begin{array}{l}\text { - wykorzystanie do ogrzewania hotelu energii } \\
\text { geotermalnej }\end{array}$ \\
\hline \begin{tabular}{l} 
- $\begin{array}{l}\text { zatrudnianie tajemniczego klienta w celu } \\
\text { dokonania zewnętrznego audytu }\end{array}$ \\
\hline- Fanpage na portalach społecznościowych
\end{tabular} & - lustro-telewizor typu Smart Mirror \\
\hline
\end{tabular}

Źródło: opracowanie własne na podstawie przeprowadzonych badań.

Tylko 17 przedsiębiorstw turystycznych w najbliższym roku planuje wprowadzenie dalszych rozwiązań $\mathrm{w}$ zakresie innowacyjności. W planach znajdują się zarówno rozwiązania produktowe jak również marketingowe, procesowe oraz organizacyjne. Do najważniejszych z nich należą:

- wprowadzenie strony internetowej przedsiębiorstwa w wersji mobilnej;

- wirtualny spacer po hotelu na stronie internetowej;

- terminal płatności zbliżeniowych;

- nowe zajęcia (np. bokwa, zumbatomic);

- segregacja śmieci przez gości hotelowych;

- ekrany dotykowe w celu przyśpieszenia procesu meldunkowego;

- nowa strona www;

- aplikacja na smartfony;

- nowe produkty i usługi (np. Korona Maratonów Świata, Korona Maratonów Górskich Europy);

- otwarcie nowych kierunków wyjazdów turystycznych (np. Albania, Macedonia);

- udogodnienia dla osób niepełnosprawnych (odpowiednie oznakowanie, poręcze, dostosowana łazienka poprzez zapewnienie odpowiedniej powierzchni manewrowej, niezbędnych uchwytów, odpowiedniej wysokości blatu, lustra);

- dodatkowe usługi dla strefy VIP (np. zamawianie biletów do teatru, transfer hotel-lotnisko, lotnisko-hotel);

- zatrudnienie osób przeprowadzających badania nad nowymi rozwiązaniami;

- zastosowanie rekuperatora, mającego na celu zmniejszenie zużycia wody i energii;

- możliwość wynajęcia przez gościa hotelowego samochodu z kierowca; 
- przygotowywanie wybranych dań z kuchni polskiej przy stoliku gościa hotelowego;

- wprowadzenie audiomarketingu;

- marketing wirusowy.

Bardzo często przedsiębiorcy nie zdawali sobie sprawy, że na innowacyjność przedsiębiorstwa składa się więcej czynników, aniżeli sama organizacja przedsiębiorstwa czy też oferowane przez nie produkty czy też usługi. Wiele pytań dotyczących innowacyjnych rozwiązań na poziomie organizacyjnym i produktowym miało charakter zastrzeżony, gdyż według osób badanych naruszały one $\mathrm{w}$ znaczący sposób politykę prywatności przedsiębiorstwa. Bardzo ciekawą odpowiedzią podczas przeprowadzania badań była deklaracja właściciela przedsiębiorstwa odnośnie do planów wprowadzenie innowacji prośrodowiskowych - nie ma takiej potrzeby, gdyż przedsiębiorstwo nie ma wpływu na środowisko. Dodatkowo przeprowadzone badania stają się często inspiracją dla przedsiębiorców, np. poprzez wprowadzenie dodatkowej zakładki na stronie internetowej przedsiębiorstwa "podziel się pomysłem". Zakładka ta ma być jednym z podstawowych narzędzi do przygotowania oferty firmy poprzez liczne konsultacje $z$ klientami. Wielu przedsiębiorców zwraca uwagę na fakt stałego działania w kierunku rozwoju innowacyjności. Dodatkowo przyjęty tok myślenia jest ukierunkowany na innowacyjność. Chociażby podczas przygotowania różnego rodzaju imprez integracyjnych następuje połączenie standardowej formuły $z$ nauką technik kreatywnych. Przedsiębiorstwa turystyczne, często uzasadniając niechęć do wprowadzenia różnego rodzaju innowacyjnych rozwiązań, wskazują na chęć stosowania klasycznych rozwiązań wynikających ze standardów. Przedsiębiorcy deklarują, że nie będą wprowadzać nowych rozwiązań, chyba że będzie to wynikało $\mathrm{z}$ narzuconych standardów innym obiektom noclegowym.

W zakresie rozwijania rozwiązań innowacyjnych przedsiębiorcy często współpracują z różnego rodzaju organizacjami. Współpraca ta ma na celu nie tylko zwiększyć konkurencyjność produktową przedsiębiorstwa, ale również organizacyjną oraz marketingową. Najczęściej współpraca jest podejmowana $\mathrm{Z}$ :

- biurem podróży przyjaznym zdrowiu turysty;

- Wielkopolskim Związkiem Pracodawców Prywatnych;

- przewodnikami miejskimi;

- Centrum Informacji Miejskiej;

- Polskim Towarzystwem Tanecznym oraz 
- hotele współpracują z biurami podróży, biura podróży współpracują $\mathrm{z}$ hotelami.

Ostatnim elementem przeprowadzonych badań było poznanie opinii wśród przedsiębiorców odnośnie do czynników ograniczających wprowadzanie innowacyjnych rozwiązań w przedsiębiorstwach turystycznych. Do najczęściej wymienianych $\mathrm{z}$ zakresie organizacji wewnętrznej przedsiębiorstwa zaliczono:

- brak zaufania do realizacji wspólnych przedsięwzięć firm i jednostek naukowo-badawczych;

- brak możliwości finansowania współpracy na linii firma-placówka naukowo-badawcza;

- bariery mentalne, wskazujące na brak uznania zasadności współpracy z jednostkami naukowo-badawczymi oraz na poszukiwanie rozwiązań innowacyjnych;

- brak wykwalifikowanego personelu.

Bariery egzogeniczne zdecydowanie stanowiły trzon, który ogranicza wprowadzanie rozwiązań innowacyjnych według badanych przedsiębiorców. Do najczęściej zaznaczanych odpowiedzi należały:

- brak odpowiednich instrumentów finansowania działalności innowacyjnej;

- brak umiejętności pozyskania środków finansowych wspierających działalność innowacyjną;

- wysokie koszty wprowadzenia innowacji produktowych i technologicznych;

- przekonanie o braku potrzeby wprowadzania innowacji organizacyjnych;

- obawa przed licznymi procedurami administracyjnymi;

- brak pewności zbytu innowacyjnego produktu/usługi;

- brak odpowiedniej infrastruktury technicznej.

\section{Podsumowanie}

Wyniki badań empirycznych wskazują na występowanie wyraźnej przewagi popytowej koncepcji innowacji. Z analiz prowadzonych wśród wielkopolskich przedsiębiorców wynika, że do najważniejszych czynników wpływających na kształtowanie się postaw innowacyjnych przedsiębiorstw tury- 
stycznych należy wymienić: możliwość dostosowania oferty do indywidualnych potrzeb turystów, znajomość zachowań i strategii konkurentów oraz wiedza i umiejętności pracowników, a także albo nawet przede wszystkim, wszelkie czynniki kształtowane przez makrootoczenie przedsiębiorstwa turystycznego.

Zdecydowaną przewagę $\mathrm{w}$ działalności innowacyjnej przypisuje się przedsiębiorstwom produkcyjnym. Podmioty turystyczne o charakterze usługowym napotykają trudności w tworzeniu podstawowych innowacji (główną barierą są wysokie koszty takich przedsięwzięć). Ich zdolność koncentruje się na kopiowaniu i adaptacji innowacji. Turystyka jest sektorem, w który bardzo szybko adaptuje się różnego rodzaju innowacje, ale słabym $\mathrm{w}$ tworzeniu własnych, oryginalnych. Jak wskazują przeprowadzone badania na rynku wielkopolskim, większość innowacji ma charakter produktowy (usługowy), co charakteryzuje specyfikę branży turystycznej. Zdecydowanie rzadziej adaptowane są rozwiązania technologiczne, organizacyjne i marketingowe.

\section{BIBLIOGRAFIA}

Działalność innowacyjna przedsiębiorstw w latach 2008-2010, 2012, Główny Urząd Statystyczny, Szczecin, www.stat.gov.pl.

FABIŃSKA M., CZYŻ P., KUBIAK K., GUNERSKA E., 2010, Akademia Zarządzania Innowacjami - materiały szkoleniowe; www.innowacyjni.com.pl.

GACZEK W.M., 2009, Konieczne warunki procesu innowacyjnego w regionie na przyktadzie Wielkopolski; www.innowacyjna-wielkopolska.pl.

MAZGAJSKA H., 2002, Aktywność innowacyjna polskich matych $i$ średnich przedsiębiorstw w procesie integracji z Unią Europejską, Prace Habilitacyjne, 4, Akademia Ekonomiczna w Poznaniu, Poznań.

RAPACZ A. (red.), 1998, Przedsiębiorstwo turystyczne na rynku, Wyd. AE we Wrocławiu, Wrocław.

SCHUMPETER J.A., 1960, Teoria rozwoju gospodarczego, PWN, Warszawa.

\section{INNOVATION IN THE TOURISM SECTOR IN GREATER POLAND}

Key words: tourism enterprise/businesses/industry, innovation, tourism services, innovation policy

\section{Summary}

Innovation in the tourism sector is increasingly becoming a source of competitive advantage. The factors which have most influenced this process include: advances in technology, increasingly demanding consumers, the limited life-span of a tourism product and growing competition. The 
paper presents the results of research into innovative solutions applied by tourism enterprises based in the Greater Poland market, taking into account above all the nature of the service industry. The most important aspects were deemed to be: innovative tourism products on offer, innovative services in the tourism sector, business and logistics management as well as relations between particular stakeholders.

The research results also indicated that as the tourism industry is service-oriented and therefore immaterial in nature, no specialised sectors for innovative enterprise which would also be responsible for the introduction of new business solutions exist. This role has clearly been assigned to the employer and, depending on the degree of enterprise development and commitment to contact with interested parties, lower levels in the tourism industry

Translated by Joanna Haracz-Lewoandowska 